\title{
Economic sustainability of Farms in Poland
}

\author{
Wioletta Wrzaszcz ${ }^{1}$, PhD; Professor Józef St. Zegar ${ }^{1}$, PhD
}

\begin{abstract}
Measuring the level of agriculture sustainability is very complex. Different proposals are presented and discussed, and still, there is no generally accepted measures of the sustainability of agriculture. This problem also concerns economic sustainability of agriculture. Sustainability of agricultural holdings determines the sustainability of agriculture, although these notions are not identical.

The Agricultural Censuses that are carried out in all the European Union countries are based on a uniform methodology. The Agricultural Census data can be used to measure the sustainability of agricultural holdings, including economic sustainability - in individual countries and for comparative analysis between them. This, without doubts, is a great advantage of this database. However, a limited scope of collected data is their weakness.

The purpose of the article is to present proposals for measuring the economic sustainability of agricultural holdings in Poland on the basis of Agricultural Census data, 2010. This article sets the following indicators of the economic sustainability: land productivity, labour profitability, farms market activity and sources of households' income and maintenance. The analysis concerns individual agricultural holdings with at least 1 ha of agricultural land and it is also carried out in the area groups.
\end{abstract}

Key Words: agriculture, environmentally sustainable farm, income,

\section{Introduction}

Measuring the sustainability of agriculture is very complex. Attempts in this field using a variety of approaches have not resulted in a generally accepted set of indicators to measure sustainability. This is true not only for agriculture but for the whole economy. The indicators measuring the sustainable socio-economic development, formulated by international organisations (OECD, 1994; CSD UN, 1996; CSD UN, 2001; CEC, 2005), are also useful in measuring the sustainable development of agriculture, however, they usually require adaptation to the specific nature of agriculture and supplementing with other indicators (OECD, 1999; CEC, 2000; OECD, 2001; EC, 2006; EC, 2008).Measuring the sustainability of agriculture and farms was also the subject of numerous scientific studies (vanLoon et al. 2005; Wilk 2005; Faber 2007; Jankowiak, Bieńkowski 2007; Majewski 2008; Toczyński et al., 2009; Sadowski, 2012; Wrzaszcz, 2012; Zegar, 2012; Zegar (ed.), 2013, Wrzaszcz, 2014). 
The difficulties in measuring the sustainability of agriculture have many causes (Woś, Zegar, 2002; van Huylenbroeck, Durand (eds.), 2003; Pretty, 2008; The Royal Society, 2009; Zegar (ed.), 2013). First of all, the term of sustainable agriculture is not clearly defined. Then, the measurement is hampered by multifunctionality of agriculture, a huge diversity of farms, different directions of the same effects on the environment and the production and economic performance, diverse aspirations of farmers and others.

Measuring the sustainability of agriculture is done generally using certain indicators relating to three aspects (orders) of sustainability, namely: environmental, economic and social. There are also attempts to formulate a synthetic indicator of agricultural sustainability (Jankowiak, Bieńkowski, 2007; Majewski, 2008;Zegar (ed.), 2013, Wrzaszcz, 2014).Most attention is paid to environmental order, which was the base for the idea of sustainable development (more precisely, a dramatic violation of this order).It can be assumed that the most relevant and developed indicators for measuring have been developed with regard to environmental order. The situation with regard to the measurement of economic and social orders is less clear. In the case of economic order, the most important indicators are those related to food security, the ability to create income for the purposes of productive investment and income of the population engaged in agricultural activity, and especially people living mainly from farming.

The sustainability of agriculture is determined by the sustainability of farms, although the latter does not exhaust the first. The sustainability of farms is the lowest level at which statistics enable to measure sustainability.

The purpose of this article is to present proposals for measuring economic sustainability of farms in Poland using the data of the Agricultural Census 2010. This data allowed for setting the indicators values of economic sustainability of agriculture based on farms' sustainability. This article adopted the following indicators of economic sustainability: land productivity, labour profitability, market orientation of farms and sources of households' income and maintenance. The analysis included individual farms with at least 1 ha of agricultural land divided into area groups.

Because agricultural censuses are carried out in all countries of the European Union and are based on a uniform methodology. The proposed use of the data from censuses to measure economic sustainability of farms and agriculture can be applied to other countries and comparative analyses between them, taking into account the different requirements of sustainability. This, undoubtedly, is a great value of databases of agricultural censuses. Such comparative studies are more difficult in relation to the measurement of environmental and social sustainability.

\section{Research method}

The analysis used statistical data collected under the Agricultural Census (AC) conducted by the Central Statistical Office in 2010. The study covered Polish individual holdings with an area of at least 1 ha of agricultural land. These farms have been synthetically characterized in four area groups, namely: 1-4.99 ha; 5-24.99 ha; 25-49.99 ha; 50 ha and more. This characteristic takes into account the size and the economic and production potential: area of agricultural land (ha), labour input (expressed in Annual 
Work Units - AWU ${ }^{1}$ ), animal population (Livestock Units $-\mathrm{LU}^{2}$ ), the standard output (EUR thousand) ${ }^{3}$ and the value of standard gross margin (European Size Units - ESU) ${ }^{4}$. Based on AC data, there were determined values of several complementary indicators that can be used in assessing the economic sustainability of farms. These indicators included the following:

- value of the standard output per hectare of agricultural land (EUR thousand/ha),

- value of the standard gross margin per full-time employee (ESU/AWU),

- the share of farms with more than $50 \%$ of commercial production in direct sales, i.e. atthe local markets, in own stores, under sale to neighbours (the so-called local market holdings),

- the share of farms selling at least $50 \%$ of the generated value of agricultural production on the market (the so-called market holdings),

- share of farms with majority household's income from agricultural activity (the socalled farmers' holdings).

The value of standard output per area unit indicates the level of land productivity. It is an important indicator of agricultural production volume in the context of food security.

The value of standard gross margin in relation to labour input can be used as a measure of the level of potential labour charges and the assessment of economic efficiency of labour. As a result, this indicator informs about potential investment and consumption funds of households and farms.

Market activity of farms indicates the scale of farms linkages with market, including the local market. Entities operating on the local market provide benefits to local communities, which are reflected not only in more convenient ways to buy goods, often for a lower price as compared with products manufactured in longer food chains, but also contribute to the development of neighbourly ties and sustaining of rural areas vitality.

The share of farmers' holdings indicates the percentage of farms oriented on active functioning on the market. The opposite group are subsistence farms where at least half of the agricultural production is used for own household's needs. The relationship between these groups of farms determines the scale of agricultural linkages

$11 \mathrm{AWU}$ is equivalent to full-time, that is 2,120 hours of work a year.

$21 \mathrm{LU}$ is a conventional unit of farm animals with a mass of $500 \mathrm{~kg}$. See tables of conversion coefficient for livestock from physical units to livestock units: (Zegar (ed.), 2013).

${ }^{3}$ Standard output is the mean of 5 years of the value of production corresponding to the average situation in the region. Total standard production of farms is the sum of the values obtained for each agricultural activity on the farm by multiplying the coefficients of the standard output for a given activity and the number of hectares or number of animals; see (Goraj et al., 2012). It is an economic category that allows for comparing the volume of production, while offsetting the impact of price fluctuations in regional and temporal terms.

${ }^{4}$ Sum of standard gross margins (SGM) - the difference between output and specific (direct) costs of all activities occurring on the farm - indicates the economic size of the farm, otherwise the productive potential of the farm. 1 ESU is equivalent to EUR 1,200. The standard gross margin is the average gross margin by region. Standard gross margin on a particular crop or animal is a standard (average of three years in a particular region) value of production obtained from one hectare or from one animal less the standard direct costs necessary to produce. 
of economic entities with the market, thus the scale of production, their market orientation and potential to ensure an adequate volume of agricultural production.

The predominant source of farm's income indicates its socio-economic type. ${ }^{5}$ This classification distinguishes the following groups:

- farmers' holdings - with majority income from agricultural activities,

- employees' households - with majority income from employment,

- entrepreneurs' households - with majority income from non-agricultural activities,

- pensioners' households - with majority income from pension,

- other -with majority income from other sources.

The assessment of environmental sustainability of farms used some basic indicators, namely (Wrzaszcz, 2014):

- balance of soil organic matter - a positive result reflects good crop rotation and systematic enrichment of the soil with humus,

- the index of vegetation cover on arable land in winter - is a synthetic indicator for the assessment of land resources, the balance of ecosystems and the degree of implementation of sustainable production system in agriculture; vegetation cover on arable land in winter should be at least $1 / 3$ of the area,

- the share of cereals in crop structure on arable land - determines the correctness of crop rotation and the degree of agrocenose biodiversity; share of cereals in crop structure should not exceed $2 / 3$ of the area,

- the number of plantgroups cultivated on arable land -indicates the possibilities of crop selection and rotation, which increases the guarantee of limiting the development of pest populations, reducing weeds and losses; at least three plantgroups should be cultivated,

- stocking density on agricultural land - provides information about the level of intensity, and also indicates the scale of the environmental impact of natural fertilizers; stocking density on agricultural land should not exceed $2 \mathrm{LU} /$ ha,

- gross balance of nitrogen in the soil - is a very important source of information on the impact of agriculture on environmental conditions, which is a consequence of the intensity and efficiency of agricultural production measured by the level of mineral fertilization, stocking density and crop yields; optimal level of nitrogen balance should not exceed $60-70 \mathrm{~kg} / \mathrm{ha}$, although the size of the excess is dependent on the local conditions in the farm.

\section{Research results}

The study included 1,488 thousand individual holdings that used at least 1 ha of agricultural land (table 1). These farms had 13,186 thousand ha of agricultural land, 1,846 thousand labour units (AWU) and 6,340 thousand livestock units (LU), EUR 16,524 million of standard output and 6,324 thousand ESU of standard gross margin. Analysed farms accounted for $78.8 \%$ of all individual holdings in Poland engaged in agricultural

${ }^{5}$ Data collected under the AC 2010 allow for the classification of farms according to the predominant source of income of a farming family, but they do not include the absolute level of income, among other thing agricultural income. 
activities and respectively $98.5 \%$ of agricultural land, $89.9 \%$ of labour inputs, $96.5 \%$ of livestock, $95.3 \%$ of standard output and $97.7 \%$ of standard gross margin 6 .

The studied population of farms is dominated by small and medium-sized farms in terms of agricultural land, while large and very large units represent a negligible proportion: respectively by area groups:1-5 ha - 54\%, 5-25 ha $-41 \%, 25-50$ ha $-4 \%, 50$ ha and more $-1.6 \%$ (Table 1). The average farm is therefore small in terms of utilized agricultural land (about $9 \mathrm{ha}$ ) and economically weak (standard gross margin amounts to 4 ESU).Such farms employ on average 1.2 AWU and the generated standard output is slightly more than EUR 11 thousand.

Table 1. Number, productive and economic characteristics of farms (average per farm)

\begin{tabular}{|l|l|l|l|l|l|l|}
\hline \multirow{2}{*}{ No. } & \multirow{2}{*}{ Specification } & \multirow{2}{*}{ Total } & \multicolumn{4}{|l|}{ By area of agricultural land (ha): } \\
\cline { 4 - 6 } & & $1-5$ & $5-25$ & $25-50$ & $\geq 50$ \\
\hline 1 & Number of farms (thousand) & 1487.6 & 798.7 & 606.3 & 58.3 & 24.2 \\
2 & Agricultural land (ha) & 8.86 & 2.56 & 10.52 & 33.66 & 115.39 \\
3 & Labour input (AWU) & 1.24 & 0.91 & 1.55 & 2.06 & 2.56 \\
4 & Livestock units (LU) & 4.26 & 0.75 & 5.87 & 22.45 & 36.09 \\
5 & Standard output (EUR thousand) & 11.11 & 3.18 & 13.73 & 45.64 & 123.59 \\
6 & Standard gross margin (ESU) & 4.25 & 0.97 & 5.49 & 19.31 & 45.14 \\
\hline
\end{tabular}

Source: Prepared on the basis of AC 2010 data.

Table 2. Economic sustainability of farms

\begin{tabular}{|l|l|l|l|l|l|l|}
\hline \multirow{2}{*}{ No. } & \multirow{2}{*}{ Specification } & \multirow{2}{*}{ Total } & \multicolumn{4}{|l|}{ By area of agricultural land (ha): } \\
\cline { 5 - 7 } & & & $1-5$ & $5-25$ & $25-50$ & $\geq 50$ \\
\hline 1 & Standard output (EUR thousand/ha) & 1.25 & 1.24 & 1.30 & 1.36 & 1.07 \\
2 & Standard gross margin (ESU/AWU) & 3.43 & 1.07 & 3.54 & 9.36 & 17.63 \\
3 & Local market holdings (\%) & 13.78 & 13.59 & 14.41 & 10.23 & 12.67 \\
4 & Market holdings (\%) & 66.03 & 54.56 & 76.69 & 98.03 & 99.96 \\
5 & Farmers' holdings (\%) & 34.78 & 14.15 & 55.03 & 86.17 & 84.04 \\
\hline
\end{tabular}

Source: Prepared on the basis of AC 2010 data.

Table 2 shows the values of the indicators that can be used to assess the economic sustainability of farms, in total and by area groups. The first mentioned indicator is standard output per hectare of agricultural land. The average land productivity was 1.25 thousand EUR/ha. Productivity of land differed slightly in plus from the average in the case of farms in area group 5-25 ha and 25-50 ha (medium and large holdings), while the smallest and the largest holdings differed in minus. Holdings of at least 50 ha were distinguished by the lowest value of the indicator. These results have pointed to a parabolic curve describing the relationship of land productivity and the farms' area. Therefore, ceteris paribus, there is required caution in the creation of farms with area above 50 ha, taking into consideration food security - supply of agricultural products.

${ }^{6}$ In Poland - excluding individual holdings - there are also 4.3 thousand farms owned by legal persons, using 1,844 thousand ha of agricultural land and producing standard output with a value of EUR 1,863 million. 
The standard gross margin per labour unit can be used as a measure of the economic efficiency of labour, potential labour charges, and capacity of the farm to income generation. The data in table 2 showed that the value of standard gross margin in a medium farm was less than 3.5 ESU/AWU. The relationship of this indicator with the farm' area is unidirectional and distinct. This is a known economic dependence, which is justified by benefits of production scale, increasing simultaneously with the farms' area (owners of large holdings have greater possibility for cost reduction, including specific/direct costs, e.g. the ability to negotiate prices when buying large batches of plant protection products, fertilizers and feed), as well as greater opportunities for efficient use of labour resources.

Market activity of farms is evidenced by percentage of local market holdings, market holdings and farmers' holdings. In the case of the first listed group, the bulk of agricultural production is sold on the local market. This group of farms is of particular importance for the local food system and indirectly for socio-economic development of local communities. In Poland, the role is played by $14 \%$ of farms. Linkages with local market of farms with area of 1-5 ha and 5-25 ha do not diverge from the average, as opposed to large farms - 25-50 ha- of which $10 \%$ are oriented on local sales. While it is not surprising that smaller farms operate more intensively on the local market (they are smaller and do not have a strong position on non-local markets allowing them to cooperate with large supermarkets, they are not able to provide large, uniform batches of goods), attention is brought to a significant proportion of very large entities - at least 50 ha - which provide the majority of commercial production on the local market.The study has demonstrated the assimilation of certain business processes on the local and non-local markets, and even on the global market, i.e. the demand for large batches of goods is reported more often, which can be provided in principle by large-scale agricultural producers or groups of producers. If observed trend increases, local agricultural producers, producing small batches of goods, may be driven out of the market by larger ones.

In the context of ensuring a sufficient supply of agri-food products, special importance is given to market holdings, i.e. those which sell at least half of the agricultural production. They are complemented by subsistence holdings, which produce mainly for own needs of households. More than two thirds of Polish farms are market holdings - a significant and numerous group. Their share ranges from 55\% among the smallest farms to $100 \%$ among the largest ones.

The last indicator of economic sustainability is the percentage of farmers' holdings- or more precisely - the share of households with a farm's owner and predominant agricultural income. Only $35 \%$ of farms is classified into this group. The share of farmers' holdings increases with their area, but in the case of the last group, i.e. $50 \mathrm{ha}$, it is slightly lower in relation to the preceding group (Figure 1).These results may indicate a relatively frequent orientation of the largest holdings on non-agricultural sources of income. These data has indicated that in the case of large farms, nonagricultural income may gain in importance due to e.g. the changeable profitability of agricultural production, significant investment and a high debt level, and thus the need to secure liquidity in the form of non-agricultural income.

In the studied population, $80 \%$ of farms derived non-agricultural income (Figure 2). Non-agricultural income was less important in the case of larger farms, although 
holdings with area of at least 50 ha more often supplemented household's budget, as compared to farms with area of 25-50 ha.

Among non-agricultural income, the household's budget was usually supplemented with income from employment (47\%). This is particularly advantageous form for holdings with own/family labour surplus. The next source of income was pensions. Traditional Polish farms are multi-generational households, so almost 30\% of households have benefits in this respect. Subsequently, farmers generated income from non-agricultural activities - every fifth farmer pointed this answer. In the case of these holdings, additional funds were mainly generated based on the farms' resources and assets (labour, land, buildings, machinery, etc.).Farmers carried out gainful non-agricultural activity related directly to the farm (own production activities or services).

Figure 1. Structure of holdings by the socio-economic type

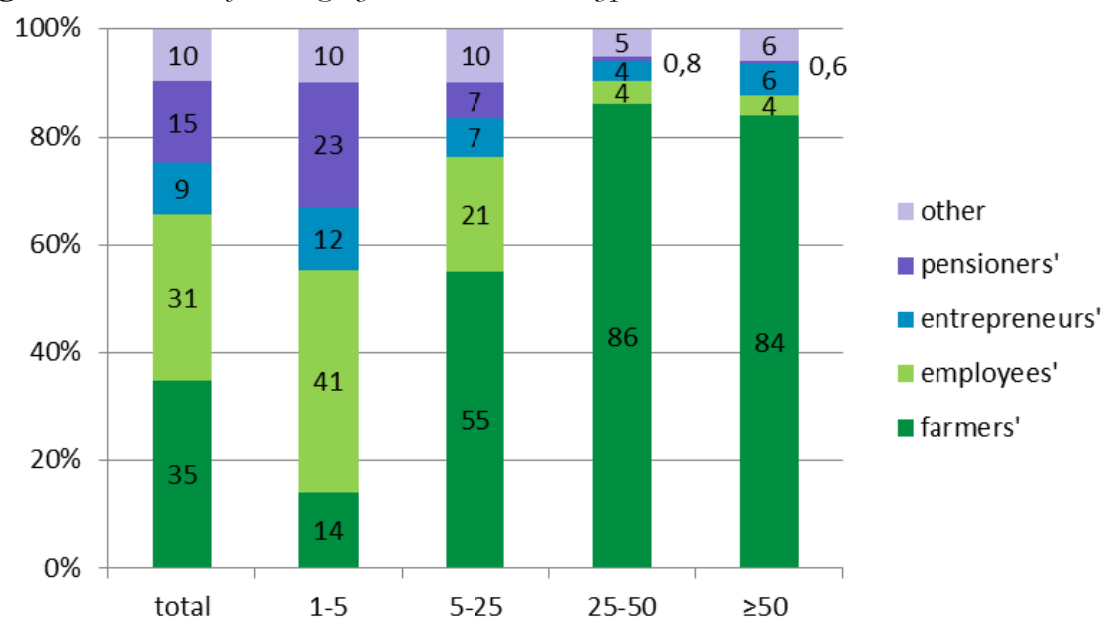

Source: Prepared on the basis of AC 2010 data.

Figure 2. Share of holdings with different sources of non-agricultural income

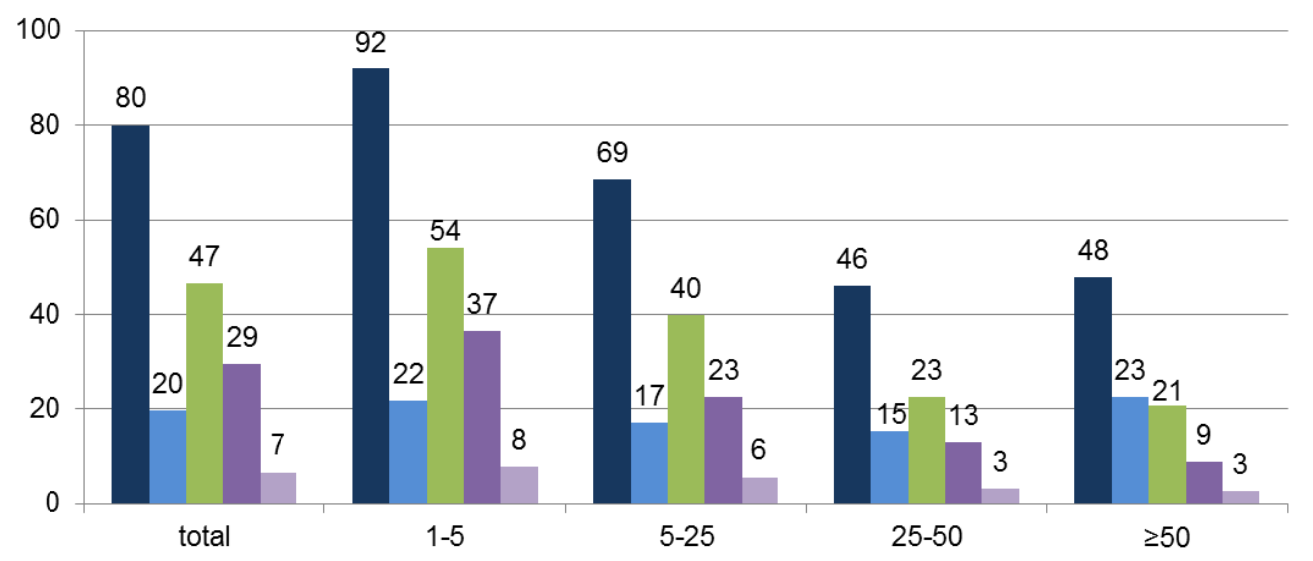

- total non-agricultural income $\|$ non-agricultural activity $₫$ contract work $\square$ pensions $\backsim$ other Source: Prepared on the basis of AC 2010 data. 
The farms' asset allowed to undertake agri-tourism and aquaculture activities or processing of agricultural products. This integration of non-agricultural activities, which complemented agricultural activities, influenced the efficient use of holdings'resources. The last-mentioned category is income from other non-wage sources (it concerns $7 \%$ of holdings).This category is quite broad and includes social assistance, child support, scholarships, revenue from capital deposits, winnings in lotteries, as well as income derived from foreign activity and lease of land.

The proportion of holdings with income from pensions, employment and other sources was noticeably decreasing among the area groups - which is fully understandable. However, the results for the last group of holdings - those with at least 50 ha -were surprising, because in this case the percentage of holdings with non-agricultural income was slightly higher than in the preceding area group. In large holdings, there are greater possibilities for complementing the household's budget, and thus conducting additional economic activity, based on the resources and assets of the whole farm (e.g.agri-tourism, sales of own agricultural and food products).

Based on the definition of sustainable development, in addition to the economic aspect, the environmental aspect is equally important. Simultaneous realization of various sustainable development objectives is the current research problem. It is important to examine the compatibility, complementarity and competitiveness of agricultural practices in terms of their environmental friendliness and economic benefits. According to research method, farms were grouped dependent on the values of economic indicators. For these groups, the percentage of households characterized by desirable level of environmental sustainability indicators was presented. The data in table 3 indicated interactions between economic and environmental sustainability of farms.

Agricultural holdings differed in the range of analysed indicators of environmental sustainability. ${ }^{7}$ Almost all farms were characterized by environmentally friendly stocking density $(98 \%)$, the dominant part of farms $(62 \%)$ provided sufficient protection against soil erosion, and in almost half of holdings the balance of organic matter remained at a positive level, which indicated its reproduction. Due to the dominance of cereals in the structure of field crops, a small portion of farms was characterized by a diverse crop structure -in every fifth holding several plant groups were cultivated. While, in every fourth holding cereals did not exceed two thirds of the sown area. Balanced amount of nitrogen was stated in a few percent of farms.

The first of the considered criteria of economic sustainability was the standard output. Table 3 shows the share of farms distinguished by the desired level of environmental sustainability indicators, depending on the value of economic results. There was observed parabolic relationship between most of the analysed environmental sustainability criteria and standard output. With the increase in standard output, there was an increase in the share of environmentally sustainable farms, but with a certain volume of production (variable, depending on the analysed environmental criterion) it

7 The average values of environmental indicators were following: balance of organic matter: $0.07 \mathrm{t} / \mathrm{ha}$; index of vegetation cover: $50.30 \%$; Cereals in crop structure: $74.94 \%$; Stocking density: $0.70 \mathrm{LU} / \mathrm{ha}$; Gross nitrogen balance: $42.16 \mathrm{~kg} / \mathrm{ha}$. 
began to decrease. The relationship between environ mental sustainability and economic potential of agricultural holdings - measured with values of standard gross margin - was similar. However stocking density increased with the standard output, which confirms the importance of livestock production in the value of agricultural production and economic results of farms. Farms with greater scale of agricultural production were also more often characterised by sufficient soil protection against erosion in the form of winter crop cover.

Table 3. Share of farms characterised by the desired level of environmental sustainability $(\%)$

\begin{tabular}{|l|l|l|l|l|l|l|l|}
\hline \multirow{2}{*}{ No. } & \multirow{2}{*}{ Specification } & \multicolumn{3}{|l|}{ Indicators* } \\
\cline { 2 - 8 } & & 1 & 2 & 3 & 4 & 5 & 6 \\
\hline 1 & Total & 45.88 & 61.67 & 25.83 & 22.14 & 97.92 & 4.46 \\
\hline & Standard output & \multicolumn{7}{|l|}{} \\
\hline 2 & <EUR 8 thousand euro & 45.36 & 60.34 & 23.12 & 13.30 & 98.84 & 3.88 \\
3 & EUR 8-25 thousand euro & 47.26 & 65.10 & 26.71 & 37.24 & 97.42 & 6.27 \\
4 & EUR 25-50 thousand euro & 45.78 & 62.18 & 38.24 & 47.72 & 91.44 & 5.04 \\
5 & EUR 50-100 thousand euro & 46.94 & 63.07 & 46.25 & 45.66 & 86.72 & 4.41 \\
6 & EUR 100-500 thousand euro & 48.21 & 65.05 & 46.35 & 32.76 & 73.52 & 2.96 \\
7 & EUR 500 thousand euro and more & 38.31 & 68.38 & 35.31 & 24.25 & 45.36 & 1.53 \\
\hline & Standard gross margin & \multicolumn{5}{|l|}{} \\
\hline 8 & <2 ESU & 44.45 & 58.95 & 23.90 & 11.45 & 99.00 & 3.57 \\
9 & 2-4 ESU & 48.27 & 66.34 & 22.91 & 29.25 & 98.27 & 6.05 \\
10 & $4-8$ ESU & 48.19 & 65.89 & 26.11 & 37.23 & 97.42 & 6.58 \\
11 & 8-16 ESU & 46.83 & 64.42 & 31.82 & 44.40 & 94.21 & 5.81 \\
12 & 16-40 ESU & 47.22 & 63.58 & 40.84 & 47.44 & 86.21 & 4.59 \\
13 & $40-100$ ESU & 49.95 & 65.43 & 46.01 & 37.24 & 77.51 & 3.59 \\
14 & 100 ESU and more & 51.10 & 67.95 & 46.19 & 31.15 & 69.50 & 2.63 \\
\hline & Linkages of farms with the market & \multicolumn{7}{|l|}{} \\
\hline 15 & Local market holdings & 47.64 & 57.52 & 26.34 & 18.89 & 98.60 & 4.73 \\
16 & Market holdings & 50.99 & 62.68 & 26.33 & 25.02 & 97.06 & 4.56 \\
17 & Farmers' holdings & 47.70 & 63.34 & 28.71 & 34.43 & 95.60 & 5.40 \\
\hline
\end{tabular}

* 1. Balance of organic matter, 2. Index of arable land vegetation cover, 3. Cereals in crop structure on arable land, 4. Number of cultivated plant groups, 5. Stocking density on agricultural land, 6. Gross nitrogen balance.

Source: Prepared on the basis of AC 2010 data.

Comparing the results of farms of different market activity and those oriented on agricultural activities with all analysed holdings, it can be concluded that the economically sustainable entities more often conduct pro-environment agricultural activities. 


\section{Conclusions}

The article presented the proposal for measuring economic sustainability of farms in Poland using the data of the Agricultural Census 2010. This article adopted the following indicators of economic sustainability: land productivity, labour profitability, market orientation of farms and sources of households' income and maintenance. There were also indicated interactions between economic and environmental sustainability of farms. The analysis included individual farms with an area of at least 1 ha of agricultural land, divided into area groups.

Based on the research, the main conclusions are as follow:

- Assessment of economic sustainability of farms is possible on the basis of agricultural censuses - applying several indicators of economic efficiency - although this approach is certainly not sufficient to exhaustively evaluate the phenomenon.

- Applied indicators inform about important economic issues associated with the scale of production and its distribution, as well as about the level of potential labour charges, sources of households' income and maintenance. The proposed indicators partly provide different information, hence an unambiguous evaluation of economic sustainability - as long as their values orient to various interpretation - is not easy.

- $\quad$ Presented values have showed a parabolic dependence of farms'area and economic indicators such as land productivity and labour profitability. It can be concluded that the increase in farms' area over a certain size- appropriate for the specific situation - is not economically justified.

- Non-agricultural income is an important source of maintenance for a large part of Polish households. Non-agricultural sources of income diminish in importance with the increase in farms' area. However, in the case of the largest farms - at least 50 ha there is a greater diversification of revenues in relation to farms of 25-50 ha. This results have indicated a desire, or need, for greater financial security of farms related to their investment activities and debt rate.

- $\quad$ The studies have showed that the analysed environmental sustainability criteria are met with varying degree by Polish farms (balance of organic matter: $46 \%$; index of arable land vegetation cover: $62 \%$; cereals in the crop structure on arable land: $26 \%$; number of cultivated plant groups: $22 \%$; stocking density on agricultural land: $98 \%$; gross nitrogen balance: $4,5 \%$ ).

- The relationship between economic and environmental sustainability generally resembles parabola. The results have pointed out that there is a complementarity between economic and environmental objectives at the farm level, but it is not infinite. At a certain level of economic benefits (the adopted measure is important here), competition is noticed.

- $\quad$ Based on comparison of market and farmers' holdings to all analysed farms, it can be stated that the economically sustainable units more often conduct proenvironment agricultural activities. 


\section{References}

Commission of the European Communities (CEC).(2000). Indicators for the Integration of Environmental Concerns into the Common Agricultural Policy. Communications from the Commission to the Council and the European Parliament. COM(2000).Brussels.

Commission of the European Communities (CEC).(2005). Sustainable Development Indicators to monitor the implementation of the EU Sustainable Development Strategy, SEC(2005)161. Brussels.

Commission on Sustainable Development, United Nations(CSD UN).(1996).Indicators of Sustainable Development: Framework and Methodologies. New York.

Commission on Sustainable Development, United Nations (CSD UN).(2001),Indicators of Sustainable Development: Guidelines and Methodologies, New York.

European Comission (EC),Schaefer, F., Luksch, U., Steinbach, N., Cabeca, J., Hanauer J. (2006).Ecological Footprint and Biodiversity. Luxemburg.

European Comission (EC).(2008). Streamlining of environmental indicators, project summary. Taskforce on the ESEA meeting of 9-10 April 2008, Eurostat.

Faber, A. (2007), Przeglad wskaźnikón rolnośrodowiskowych zalecanych do stosowana w ocenie zrównoważonego gospodarowania $w$ rolnictwie. IN: A. Harasim (ed.), Sprawdzenie praydatności wskaźników do oceny zrównoważonego gospodarowania zasobami środowiska rolniczego w wybranych gospodarstwach, gminach $i$ województwach.Studia i Raporty IUNG-PIB, No. 5, Puławy.

Goraj, L., Bocian, M., Cholewa, I., Nachtman, G., Tarasiuk, R. (2012). Współczynnikei Standardowej Produkcji „2007” dla celów Wspólnotowej Typologii Gospodarstw Rolnych. Warszawa.

Huylenbroeck, G. van, Durand, G. (eds.).(2003).Multifunctional Agriculture. A New Paradigm for European Agriculture and Rural Development, Ashgate, Hampshire-Burlington.

Jankowiak, J., Bieńkowski, J. (2007).Syntetyczna ocena żównoważonego rozwoju gospodarstw rolnych.Fragmenta Agronomia.Vol. 3, No. 95, pp. 192-2004.Puławy

Loon, G. W. van, Patil, S. G., Hugar, L. B. (2005), Agricultural Sustainability. Strategies for Assessment. SAGE Publications,New Delhi/Thousand Oaks/London.

Majewski, E.(2008). Trwaty roz̧wój i trwałe rolnictwo - teoria a praktyka gospodarstw rolniçych. SGGW. Warszawa.

OECD. (1994).Environmental indicators: Theory and Practice. Core Set. OECD. Paris.

OECD. (1999).Environmental indicators for agriculture: Issues and design. Proceeding of the York Workshop. Vol. 2. Paris.

OECD. (2001).Environmental indicators for agriculture: Methods and results. Executive Summary. Vol.3. Paris.

Pretty, J. (2008). Agricultural Sustainability: Concepts, Principles and Evidence. Philosophical Transactions of the Royal Society B.No. 363.pp. 447-465, rstb.royalsocietypublishing.org.

Sadowski, A. (2012).Zrównoważony rozwój gospodarstw rolnych z uwzględnieniem wpływu wspólnej polityki rolnej Unii Europejskiej. RozprawyNaukoweNo. 447. UniwersytetPrzyrodniczy. Poznań.

The Royal Society.(2009).Reaping the Benefits: Science and the Sustainable Intensification of Global Agriculture. London.

Toczyński, T., Wrzaszcz, W., Zegar, J.St. (2009.)Z badań nad rolnictwem społecznie zrównoważonym (8).Zrównoważenie polskiego rolnictwa w swietle danych statystyki publicznej. IERiGŻ-PIB.No. 161. Warszawa.

Wilk, W. (2005).Koncepija wykorzystania danych rachunkowych FADN do ustalenia stopnia zrównoważenia gospodarstw rolnych. IN:J.St. Zegar (ed.), Koncepcja badań nad rolnictwem społecznie zrównoważonym. IERiGŻ-PIB.pp. 134-152. Warszawa.

Woś, A., Zegar, J.St. (2002).Rolnictwo społecznie zৃrównowažone. IERiGŻ. Warszawa.

Wrzaszcz, W. (2012).Poziom zrównoważenia indywidualnych gospodarstw rolnych w Polsce (na podstawie danych FADN). IERiGŻ-PIB.Studia i Monografie.No. 155. Warszawa.

Wrzaszcz,W.(2014).Sustainability of Agricultural Holdings in Poland. IERiGŻ-PIB.Studia i Monografie.No. 161. Warszawa.

Zegar, J.St. (2012). Wspótczesne wyz̨wania rolnictwa, WN PWN. Warszawa.

Zegar, J. St. (ed.). (2013). Zrównoważenie polskiego rolnictwa. Powszechny Spis Rolny 2013. Authors: Toczyński, T., Wrzaszcz, W., Zegar J. St., GUS, Warszawa. 
